\title{
Bourdieu e a nova sociologia econômica
}

Cécile Raud

Introdução

D e acordo com Swedberg (1991), existem três tradições principais em Sociologia E conômica: a tradição alemã deW irtschaftssoziologie (1890-1930), a tradição francesa de sociol ogi eéconomique (1890-1930) ea tradição norteamericana de economy and society (anos de 1950). No que diz respeito à tradição francesa, representada por autores como É mile D urkheim, M arcel $M$ auss, François Simiand ou $M$ aurice $H$ albwachs, el a compartilharia com a tradição alemã uma ênfase no papel das instituições econômicas e na dimensão cultural esimbólica dosfenômenos econômicos, além da recomendação de que o método da sociologia econômica deveria ser comparativo e histórico. A principal diferença entre ambas as tradições residiria no lugar da Sociologia Econômica: para os sociólogos alemães, ela poderia complementar a teoria econômica, cuja legitimidade não está sendo questionada, enquanto para osfranceses ela deveria substituir uma teoria econômica inútil, pois baseada em premissas irrealistas.

I gualmente, Steiner (1998) posiciona Bourdieu, como herdeiro de D urkheim eVeblen, no campo "crítico" da Sociologia Econômica, que pretende substituir a teoria econômica. M ais tarde, ele identifica em Auguste Comte, Émile D urkheim e Pierre Bourdieu uma "tradição francesa de crítica sociológica da economia política", fundamentada essencialmente em 
duas apreciações de ordem metodológica: a análise dos fatos econômicos independentemente dos outros fatos sociais e a natureza do homo oeconomicus (cf. Steiner, 2005). D e maneira semelhante, Lebaron (2001) vê uma filiação entre Bourdieu, de um lado, e Simiand e $\mathrm{H}$ albwachs, de outro, no que diz respeito ao projeto de substituir a ciência econômica por uma "economia sociológica". Ele argumenta nesse sentido, tentando mostrar as semelhanças nas reflexões epistemológicas e nas posi ções metodológicas desses três autores. D efato, todos criticam o caráter normativo eideológico da ciência econômica, o queé, aliás, uma constante entre os sociólogos economistas franceses desde Émile D urkheim, no quadro de uma tradição iniciada por Auguste Comte.

Lebaron (2001) defende a tese de que Bourdieu superou seus ilustres mestres ao fundamentar sua crítica da ciência econômica na sociologia do conhecimento científico, o que lhe permite evidenciar que os erros científicos encontram seu princípio nos obstáculos sociais à aquisição do conhecimento (cf. Bourdieu, C hamboredon ePasseron, 1968, apud Lebaron, 2001, p. 57). A "falácia escolástica" decorre então da posição particular ocupada pelo cientista no espaço social, levando-o a considerar como princípio das práticas dosagentes sociais suas próprias representações dessas práticas ou os modelos teóricos elaborados para explicá-las, ou seja, a "colocar seu pensamento pensando na cabeça dos agentes agindo" (Bourdieu, 2000, p. 19). As estruturas mentais doscientistas são, assim, suscetíveis decontaminar-sepelas classificações sociais preexistentes, que funcionam como representações préformadas da realidade estudada (cf. Lebaron, 2001). Em particular, éo caso de certas categorias ou pressupostos implícitos da ciência econômica, como a noção de mercado, "mito inteligente", ou a visão do agente econômico (cf. Bourdieu, 2005, p. 20). Por isso Bourdieu defende a necessidade da ruptura epistemológica durkheimiana com relação às prénoções de senso comum, e o esforço para elaborar uma sociologia econômica baseada em novos conceitos, como os de campo ehabitus (cf. Bourdieu, 2000; 2005).

D e acordo com Steiner (2005), a sociologia econômica proposta por Bourdieu, de maneira semelhante a C omte e D urkheim, caracteriza-se por levar em conta três dimensões esquecidas pela ciência econômica: histórica, social e política. D e fato, no quadro do estruturalismo genético, Bourdieu afirma a necessidade de reconstruir a gênese das disposições econômicas do agenteeconômico, assim como a gênesedo próprio campo econômico: "[...] tudo o quea ortodoxia econômica considera como um puro dado, a oferta, a demanda, o mercado, éproduto deuma construção social, éum tipo dearte- 
fato histórico, do qual somente a história pode dar conta" (Bourdieu, 2005, p. 17). A respeito da dimensão social, podemos citar a preocupação com a análise das condições econômicas e sociais das disposições econômicas, ou, como diz Bourdieu (2000), da "gênese social dos sistemas de preferências". Finalmente, a dimen são política encontra-sepresentenas reflexões a respeito das relações entre o campo econômico e o Estado, assim como na ênfase na questão da dominação e do poder. Além dessas dimensões, Steiner (2005) defende a idéia de que uma das características da sociologia econômica de D urkheim e de Bourdieu reside na sua sociologia do conhecimento econômico, por meio da análise das crenças econômicas ${ }^{1}$. D esenvolveremos essas diversas dimensões ao longo deste artigo.

N um texto posterior, Swedberg (2004, p. 12) aprofunda sua análisecomparativa ao afirmar: "[...] a sociologia econômica francesa é muito original e também muito distinta da sociologia econômica norte-americana". Com relação a esta última, em particular, "a análise de Bourdieu é consideravelmente mais realista" devido à ênfase na questão dos interesses dos atores. Com base nisso, Swedberg $(2003 ; 2004)$ advoga seguir a trilha iniciada por W eber e perpetuada por Bourdieu no sentido de atribuir devida importância aos interesses, sobretudo, na sociologia econômica, e relativizar assim 0 papel assumido pelas relações sociais². Essa abordagem é fundamental, segundo ele, pois permite explicar a origem dos conflitos, que só ocorrem por causa de um antagonismo de interesses.

D iante disso, pretendemos proceder a uma análise da sociologia econômica de PierreB Bourdieu, em particular de sua sociologia do mercado, para averiguar a existência das três dimensões "esquecidas pela teoria econômica" - histórica, social e política - , além da reflexão sobre as crenças econômicas, e verificar assim sua inserção na "tradição francesa da Sociologia Econômica". 0 segundo eixo que norteará esta reflexão consiste em indagar até que ponto Bourdieu consegue elaborar uma teoria alternativa à teoria econômica, tendo em vista sua ênfasena questão dos interesses dos agentes sociais. Para tanto, focalizaremos nossa análise essencialmente em dois textos de Bourdieu, que podem ser vistos como seu manifesto em Sociologia Econômica: 0 artigo Le champs économique, publicado em 1997, e o livro Les structures sociales de l'économie, publicado em 2000, ambos resultantes de uma exaustiva pesquisa empírica sobre o mercado da casa própria na França, e nos quais Bourdieu sistematiza os princípios de sua Sociologia Econômica. No entanto, não nos limitaremos a essas duas fontes, já que Bourdieu demonstrou ao longo de sua obra um interesse pelas questões
1. Para Garcia-Parpet (2003), também, a principal contribuição de Bourdieu à Sociologia Econômica residena sua reflexão a respeito das crenças econômicas, por meio do conceito de habitus.

2. Isso constitui uma referência explícita à análise estrutural, em particular de M ark Gra novetter, quefocaliza as redes de relações pessoais. No entanto, a análise em termos de rede não pode ser vista como inteiramente oposta a uma análise em termos deinteresse (cf. Raud-M attedi, 2005b). 0 próprio Swedberg (2003) reconhece a não-exclusividade dessas duas abordagens, uma vez que recomenda levar em conta ambas, com ajus tificativa de que os interesses são definidose expressos por meio das relações sociais. 
3. Ver, por exemplo, Travail et travailleurs en Algérie, publicado em 1963.

4. Bourdieu (2000, p.

22) identifica um último "princípio de distorsão "nas preocupações normativas de uma ciência aplicada, influenciada pelas demandas políticas. Ele critica assim o deslizamento ideológico da Ciência Econômica, que está cada vez mais setornando uma "ciência de Estado", ponto em queseencontranovamente certa semeIhança com as acusações de ideologia e abordagem normativa direcionadas por D urkheim (1984) àE conomia Política. M as não desenvolveremos esse temano presentetexto.

5.Tomando como ponto de partida a de finição da economia política de Stuart M ill (1984), Émile Durkheim (1984) questiona se existe realmente uma esfera da atividade social em que o desejo de riqueza desempenhe esse papel preponderante. econômicas, que se afirmou desde seus primeiros trabalhos, a respeito do processo de adaptação da população ao capitalismo na Argélia’, "e neles já podem ser encontradas as formas mais elaboradas de uma sociologia econômica" (G arcia-Parpet, 2003, p. 139). Seguindo a própria recomendação de Bourdieu, organizaremos nossa reflexão ao redor dos dois conceitoschave, os de campo e de habitus. Antes disso, no entanto, iniciaremos pela análise das críticas direcionadas por Bourdieu à teoria econômica.

As críticas de Bourdieu à teoria econômica: imperialismo ou falta de ambição?

Entre as numerosas críticas de Bourdieu à teoria econômica, encontramos a crítica da metodologia, da noção de homo oeconomicus (pressuposto básico da C iênciaEconômica, do ator econômico racional einteressado), do etnocentrismo e da visão a-histórica da ciência econômica, assim como uma

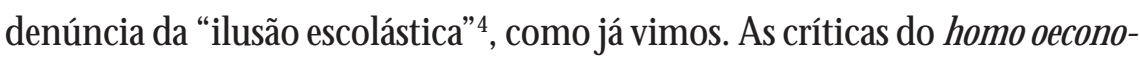
mi cussão um dos argumentos recorrentes dos sociólogos economistas desde Comte. Bourdieu fala, a esse respeito, de "criação fictícia" (1963, p. 25), de "monstro antropológico" (2005, p. 46) ou de uma "antropologia imaginária" (I dem, p. 51). Reconhecendo sua dívida intelectual para com D urkheim e Veblen, ele caracteriza a teoria da ação racional como uma "epistemologia dedutivista", cujos axiomas são irrealistas, uma "filosofia intelectualista, que concebe os agentes como puras consciências sem história" e uma "visão atomística edescontinuísta" (I dem, pp. 51-52). Em particular, cobra da "filosofia individual ista da microeconomia do agente" sua visão de atores "intercambiáveis e livres de qualquer pressão estrutural" (I dem, p. 16). Contra uma ciência etnocêntrica, quetendea "creditar universalmenteosagentes da aptidão à conduta econômica racional", elereivindica a necessidade deumaanálise das "condições econômicas eculturais do acesso a essa aptidão" (2000, p. 16). Paral elamente, "contra a visão a-histórica da ciência econômica", ele afirma a importância de "reconstruir, de um lado, a gênese das disposições econômicas do agente econômico [... ], e, do outro lado, a gênese do próprio campo econômico" (I dem, p. 16).

Retomando uma crítica elaborada por D urkheim já em 1895, Bourdieu denuncia um procedimento metodológico da ciência econômica, a abstração 5 . "A ciência que chamamos 'economia' se fundamenta numa abstração originária que consisteem dissociar uma categoria particular de práticas, ou uma dimensão particular detoda prática, da ordem social na qual toda prática humana está imersa" (2000, p. 11). Partindo desse pressuposto, e apesar 
de reconhecer que a autonomia da teoria econômica está em parte baseada na autonomia do próprio campo econômico, ponto com o qual concorda, Bourdieu (2000) defende seu projeto de elaborar uma teoria alternativa, baseada em novos conceitos (sobretudo os de habituse de campo), quepretendereinserir o econômico no social. Eleadvoga então tratar o fato econômico como um "fato social total", no sentido deM arcel M auss, na medida em que "o mundo social está inteiramente presente em cada ação 'econômica'" (I dem, pp. 11 e13). E ainda, utilizando uma expressão muito parecida com as análises da N ova Sociologia Econômica, especialmente com a noção de enraizamento cunhada por Polanyi $(1980)^{6}$ e resgatada por Granovetter (1985), Bourdieu afirma, no quadro de mais uma crítica à ciência econômica, que "o cálculo estritamente utilitarista não pode dar conta completamente de práticas que permanecem imersas no não-econômico" (I dem, p. 21). N essesentido, a ciência econômica, tal como épraticada, não élegítima e deveser substituída por uma sociologia econômica:

[...] aimersão daeconomia no social étal que, por legítimas que sejam as abstraç̃ões realizadas para as necessidades da análise, épreciso ter claro que o verdadeiro objeto de uma verdadeira economia das práticas não éoutra coisa, em última análise, senão a economia das condições de produção e de reprodução dos agentes e das instituições de produção e de reprodução econômica, cultural e social, isto é, o próprio objeto da sociologia na sua definição mais completa emais geral (2000, pp. 25-26).

No entanto, nem sempre Bourdieu assumiu essa postura com relação aos pressupostos da ciência econômica.

$\mathrm{N}$ um dos primeiros textos em que tentou sistematizar suas reflexões a respeito das modalidades e dos condicionantes da ação social, ele afirmava que convém

[...] abandonar a dicotomia do econômico e do não-econômico que proíbe apreender a ciência das práticas "econômicas" como caso particular de uma ciência capaz de tratar todas as práticas, inclusive aquelas que se reivindicam desinteressadas ou gratuitas, portanto libertadas da "economia" como práticas econômicas, orientadas para a maximização do lucro material ou simbólico (Bourdieu, 1980a, p. 209).

Ele esboça, assim, os grandes traços de "uma teoria sociológica geral que não seria nada mais do que uma economia política generalizada" (Caillé, 1987, p. 130). D efato, para Bourdieu, a análise das ações econômicas deve
6. Bourdieu (2000, p. 11), aliás, cita a noção de embeddedness de Karl Polanyi. 
ria ser realizada pela sociologia - o que D urkheim (1975) já reivindicava - , não porque as ações econômicas seriam um tipo de ação social, mas porque todas as ações sociais obedeceriam à mesma lógica das ações econômicas (ponto com o qual D urkheim obviamente não poderia concordar).

A teoria das práticas propriamente econômicas é um caso particular de uma teoria geral da economia das práticas. M esmo quando elas dão todas as aparências do desinteresse porque escapam à lógica do interesse "econômico" (no sentido restrito) e porquese orientam para alvos não materiais edificilmente quantificáveis, como nas sociedades "précapitalistas" ou na esfera cultural das sociedades capitali itas, as práticas não cessam de obedecer a uma lógica econômica (Bourdieu, 1980a, p. 209).

7.0 "imperialismo econômico" da sociologia deBourdieu aparecede maneira nítida nesta análisedas estratégiasfa miliares, em que vários dos âmbitos da vida social podem ser analisados em termos de interesse, lucro, investimento, mercado e capital: "O sistema das estratégias de reprodução deumaunidadedoméstica depende dos lucros diferenciaisqueelapode esperar dos diferentesinvestimentos em função dos poderes efetivos sobre os diferentes mecanismosinstitucionalizados (mercado econômico, mercado escolar, mercado matrimonial), assegurados pelo volumee a estrutura de seu capital" (Bourdieu, 1994, p. 7).
Assim, "o que propõe Bourdieu não é pensar o econômico como um subconjunto da sociedade, mas, pelo contrário, conceitualizar a relação social como uma modalidade ampliada da relação econômica" (C aillé, 1987, p. 138). Caillé salienta assim que, paradoxalmente, a crítica de Bourdieu aos economistas consiste não numa utilização abusiva do modelo do homo oeconomicus, mas, pelo contrário, na sua utilização restrita a uma área específica da vida social. Também para Alexander "[...] Bourdieu estende a redução instrumental da ação - a prática como busca do lucro - a todos os âmbitos da vida social [...]. 0 problema da teoria econômica não reside afinal no fato de ela ser conceitualmente imperialista, mas, de forma paradoxal, de não ser ambiciosa o suficiente" (Alexander, 2000, p. 89). D efato, Bourdieu ironiza a incapacidade da teoria econômica de explicar outras formas da ação social que não seja a econômica, apesar de elas também serem orientadas pela busca do interesse.

Como ele não conhece outras espécies de interesse além daquele que o capital ismo produziu [...], o economismo não pode integrar em suas análises emenos ainda em seus cálculos nenhuma das formas do interesse "não-econômico": como se o cálculo econômico tivesse conseguido apropriar-se do terreno objetivamente entregueà lógica impiedosa do "interesse puro", como diz M arx, apenas deixando uma ilhota sagrada, milagrosamente poupada pela "água gelada do cálculo egoísta", asilo do que não tem preço, por excesso ou por falta (Bourdieu, 1980a, p. 192) ${ }^{7}$.

Assim, parece que Bourdieu assume uma postura ambígua com relação à ciência econômica. Retomaremos esse ponto no quadro da análise do habitus do ator econômico. 
0 mercado como campo de lutas

B ourdieu caracteriza o mercado como um "mito inteligente" e sublinha que, como já foi notado freqüentemente, "a noção demercado quasenunca é definida, e menos ainda discutida" (2005, p. 20). M as reconhece que essa ausência não étão ilógica, devido à abstração progressiva da noção demercado no decorrer da revolução marginal ista: “ $N$ a verdade, essa acusação ritual não faz muito sentido, na medida em que, com a revolução marginalista, 0 mercado cessa de ser al go concreto para se tornar um conceito abstrato sem referência empírica" (I dem, p. 20). Rompendo com essa tradição, eno quadro da orientação atual da sociologia contemporânea, Bourdieu define 0 mercado como uma "construção social" (2005, p. 40): éo lugar deencontro entrea demanda ea oferta, ambas social mente construídas.

Ilustrando a tendência da sociedade moderna à diferenciação, analisada por vários sociólogos desde Spencer, passando por D urkheim e Weber, Bourdieu reconhece a existência de uma esfera econômica, a "esfera das trocas de mercado", "o campo econômico como cosmo obedecendo a suas próprias leis", no seio do qual "o cálculo dos lucros individuais impôs-se como princípio de ação dominante" (2005, pp. 18-19). É interessante apontar novamente para certa ambigüidade de Bourdieu, que, de um lado, critica o procedimento abstrato da ciência econômica e advoga tratar 0 fato econômico como fato social total, como já vimos, e, de outro, reconhece a existência de uma esfera econômica autônoma, referindo-se à "[...] revolução ética, ao término da qual a economia pôde se constituir como tal, na objetividade de um universo separado, regido por suas próprias leis, as do cálculo interessado e da concorrência sem limites para o lucro" (Bourdieu, 2000, p. 18; grifo do autor). D e fato, com sua noção de campo, ele subentende quea definição do fato econômico não é problemática. A idéia de diferenciação e de autonomização contida na noção de campo produz a ilusão da separação radical das diversas atividades sociais (cf. Lahire, 2001). No entanto, dizer que o fato econômico deve ser tratado como um fato social total é afirmar a dificuldade de delimitar os contornos do "econômico", ponto a respeito do qual D urkheim (1984) já debatia com John Stuart M ill e a economia política de maneira geral. "D esde os debates entre Comte e M ill em meados do século XIX, a definição de uma esfera econômica suscetível de ser estudada de uma maneira separada éum problema e constitui uma das razões fundamentais das tensões entre economistas e sociólogos"' (Steiner, 2002, p. 45). 
8.Sobre esse ponto, ver também Convert (2003).

\section{Apesar dessas afir-} mações veementes, não podemos esquecer a postura ambígua de Bourdieu a respeito da relação entre práticas econômicas e práticas sociais, como já salientado.
$\mathrm{N}$ a verdade, Bourdieu parece se distanciar da ciência econômica na medida em que, ainda que reconheça a autonomização relativa da esfera econômica, também torna mais complexa sua análise com quatro dimensões sociológicas. Em primeiro lugar, ao mesmo tempo em que Bourdieu afirma que o campo econômico se distingue dos outros campos por uma busca aberta da "maximização do lucro material individual", ele reconhece, contra G ary Becker e toda a tradição do imperialismo econômico, que "a emergência de tal universo não implica de modo algum a extensão a todas as esferas da existência da lógica da troca mercantil" (Bourdieu, 2005, p. 22). D e fato, o processo de diferenciação e de autonomização das esferas sociais acarreta uma "explosão da noção de interesse; há tantas formas de libido, tantos tipos de 'interesse', quanto há campos. Cada campo, ao se produzir, produz uma forma de interesse que, do ponto de vista de outro campo, pode parecer desinteresse (ou absurdo, falta de realismo, loucura etc.)" (Bourdieu, 1996, p. 149; grifo do autor). Swedberg (2003) lembra que Bourdieu critica os economistas por sua noção a-histórica de interesse e por generalizar a outras esferas sociais o interesse econômi co $^{8}$. N esse sentido, Bourdieu afirma se posicionar "nos antípodas do economicismo, que consiste em aplicar a todos os universos o nomos característico do campo econômico" (Bourdieu, 1996, p. 148; grifo do autor). A generalização abusiva de $G$ ary Becker e autores afins do pressuposto do ator econômico calculador e interessado (pelo dinheiro) a outras esferas, além da esfera econômica, um empreendimento teórico no qual "nada mais escapa à explicação pelo agente maximizador", é portanto denunciada por Bourdieu como um exemplo típico de "falácia escolástica" (2005, p. 46) ${ }^{9}$. Segundo, ele lembra que "as trocas nunca são completamente reduzidas a sua dimensão econômica", ou seja, citando Durkheim (1995), "os contratos sempre têm cláusulas não-contratuais" (Bourdieu, 2005, p. 22). D e fato, D urkheim, e todas as análises sociológicas do mercado depois dele, lembra que a viabilidade do contrato depende da existência de um fundo institucional composto pela Tradição, a M oral e o Direito (cf. Raud-M attedi, 2005a). Terceiro, como veremos logo em seguida, os atores econômicos de Bourdieu não são iguais e intercambiáveis, como nos modelos econômicos, mas dotados de diferentes quantidades e formas de poder, e exercendo, ou sofrendo, dominação. Enfim, no quadro de uma análise de tipo weberiano, Bourdieu insiste na importância de considerar a emergência da esfera econômica como um fenômeno cultural, cuja gênese deve ser objeto de investigação. 
Lembramos que o campo é um subsistema social, ou um espaço estruturado de posições, onde os diferentes agentes que ocupam as diversas posições lutam, tendo em vista a apropriação do capital específico ao campo e/ ou a redefinição desse capital. C omo o capital está distribuído de maneira desigual no seio do campo, existem dominantesedominados. $D$ ando continuidadeà análise weberiana do mercado, segundo a qual "toda troca racionalmenteorientadaéa conclusão medianteum compromisso deuma prévia luta de interesses aberta ou latente" (W eber, 1991, p. 43) ${ }^{10}$, Bourdieu define o campo econômico como um "campo de lutas" 11 , isto é, um "campo de ação social mente construído onde se afrontam agentes dotados de recursos diferentes" (2005, p. 33) ${ }^{12}$. Essa dotação derecursos dependeda quantidade eda qualidade do capital decada agente:

A força ligada a um ator depende de seus diferentes recursos [...], isto é, mais precisamente, do volume e da estrutura do capital que ele possui, sob suas diferentes formas: capital financeiro, atual ou potencial, capital cultural [...], capital tecnológico, capital jurídico, capital organizacional [...], capital comercial e capital simbólico" (Idem, pp. 24-25).

Em função desses recursos, os agentes elaboram estratégias de ação, no âmbito dos limites impostos pela estrutura do campo, em particular pelo seu grau de concentração. Bourdieu rejeita, assim, a postura que consistiria em opor uma abordagem em termos de estrutura a uma abordagem em termos de estratégia: "N ão é preciso escolher entre uma visão puramente estrutural e uma visão estratégica: as estratégias mais conscientemente elaboradas só podem se exercer nos limites e nas direções que Ihes são atribuídos pelas pressões estruturais e pelo conhecimento, desigualmente distribuído, dessas pressões" (I dem, p. 28). Levar em conta a dotação diferencial de capital implica levar em conta a existência de relações de dominação no seio do campo econômico, ou seja, a existência de empresas dominantes e dominadas. N esse sentido, Bourdieu rompe com a teoria econômica na qual só interagem atores iguais, ao menos nos modelos de concorrência pura e perfeita (cf. Boyer, 2003; Brochier, 1987), e tem o mérito de destacar a dimensão política do mercado.

Essa visão de uma oferta que "se apresenta como um espaço diferenciado e estruturado de empresas concorrentes, cujas estratégias dependem dosoutros concorrentes" (2000, p. 37; grifo do autor), émuito parecida com a análiseestrutural de $\mathrm{H}$ arrison W hite (1981), na qual a oferta não se constitui de um
10. A respeito da sociologia weberiana do mercado, ver Raud$M$ attedi (2005a).

11. Esta definição é muito parecida com a metáfora do "mercado como política" deFligstein (1996).

12. Lembrando aanálise weberiana do dualismo ético edo mercado como conceito oposto ao de comunidade, Bourdieu conta quena Argélia de 1960 "asrelaçõesreduzidasàsuadimensão puramente 'econômica' são concebidas como relações de guerra, que só podem estabdecer-seentre estrangeiros" (2003, p. 80). E, nessemercado, onde se enfrentam indivíduos movidos unicamente pela busca de seu interesse material, a incerteza com relação à qualidade do bem (burro ou boi, por exemplo) implica a mobilização dasrelaçōespessoaispara reduziro risco deoportunismo. N essecaso, Bourdieu comprova resultadoshojeamplamenteestudados no quadro da análiseestrutural (ver por exemplo DiM aggio e Louch, 1998; Granovetter, 1974; 1985). Pelo contrário, no séo da comunidadetradicional ar- 
geliana, Bourdieu (2003) mostra que as relações econômicasetãoprofundamente enraizadas nas relações sociais caracterizadas pela reciprocidade, ou seja, pela lógicada dádiva, reencontrando assim fatosjá observados por Polanyi (1980) e M auss (2001) em outras sociedadestradicionais.

13. Weber (1991) via o mercado como o resultado de duas formas de interação social: atroca, simultaneamenteorientada para o parceiro e paraosconcorrentes, ea competição (luta sobre os preçosentreo cliente e 0 vendedor, e entre concorrentes, tanto vendedores como clientes).

14. Podemossugerirque Bourdieu elabora uma sociologia relacional, no sentido de Emirbayer (1997), ao afirmar: "O peso associado a um agentedependedetodos osoutrospontosedasrelações entre todos os pontos, isto é, de todo 0 espaço compreendido como uma constelação relacional" (2005, p. 24).

15. D e fato, Bourdieu $(2000 ; 2005)$ refina sua análise, mostrando que a própria empresa funciona à maneira de um campo, sendo suasestra- agregado de vendedores independentes, como na teoria econômica, mas de um conjunto deprodutores queficam seobservando. Assim, o fato dequeas empresas concorrentes não param de se espiar explica a elaboração quasesimultânea de model os semelhantes de residências em empresas que ocupam posições vizinhas no campo dos produtores (cf. Bourdieu, 2000). M as Bourdieu afirma se distanciar das concepções tanto de M ax Weber (1991) ${ }^{13}$ como deH arrison W hite. Ambosteriam o mérito de sublinhar a influência dos concorrentes na estratégia dos parceiros da troca, mas acabaram caindo numa visão interacionista, esquecendo as pressões inerentes à posição ocupada na estrutura do campo (cf. Bourdieu, 2005). I gualmente, Bourdieu criticava os estruturalistas, como G ranovetter, que "apenas se desgrudam da visão benthamiana e do 'individualismo metodológico', para cair na visão interacionista" que ignora a pressão estrutural do campo (cf. Idem, p. 31). Ele reivindica então a herança de Simmel, ao considerar a competição no mercado um "conflito indireto", isto é, não dirigido diretamente contra o concorrente, mas mediatizado pelo campo (cf. Idem, p. 45). 0 u seja, à visão interacionista, quepensa em termos deinfluência direta, épreciso opor uma visão estrutural, queleveem conta os "efeitosdecampo" (I dem, p. 26; grifo do autor). É menos por meio de ações diretas do que do peso queelas detêm na estrutura do campo (peso que depende do volume e da estrutura do capital detido) que as empresas dominantes pressionam as empresas dominadas e influenciam suas estratégias ${ }^{14}$. 0 s empresários não escolhem "livremente"; pelo contrário, suas decisões sofrem o peso detoda a estrutura do campo dos construtores. Além disso, as estratégias das empresas não dependem somente da posição ocupada na estrutura do campo, mas também da estrutura das posições de poder no seio da empresa ${ }^{15}$. No quadro dessa concepção demercado, eretomando um resultado jáidentificado por $W$ eber ${ }^{16}$, o preço não éo fruto "automático, mecânico einstantâneo" demecanismos concorrenciais, masuma conseqüência das relações de poder existentes no campo da produção (cf. Idem, p. 29), ponto no qual Bourdieu rompenovamentecom a teoriaeconômica preval ecente. Asempresas dominantestêm, assim, o poder de determinar tanto os preços de compra como os preços de vendae, portanto, oslucros.

Como em Fligstein (1996), o mercado de Bourdieu consiste num jogo temporariamente estabilizado, cujas regras são provisoriamenterespeitadas. $N$ esse quadro, a dominação de uma empresa reside em essência na sua capacidade de impor às outras sua própria definição do jogo. "Ela constitui um ponto de referência obrigatório para seus concorrentes, que, façam o quefi- 
zerem, são intimados a tomar posição em relação a ela, ativa ou passivamente" (Bourdieu, 2005, p. 36). D e um lado, Bourdieu insiste na dimensão estática do fenômeno da reprodução do campo, por meio das "barreiras à entrada" de novas empresas, estabelecidas pela distribuição desigual dos recursos, em particular em termos deeconomias deescala a devantagenstecnológicas deti das pelas empresas dominantes (I dem, p. 27). D e outro lado, Boyer defende outra interpretação da teoria de Bourdieu: "Enquanto uma leitura superficial sugere uma fatalidade da reprodução social, na verdade todo o esforço analítico orienta-se para a revelação dosfatores demudançae de transformação" (Boyer, 2003, p. 69). 0 próprio Bourdieu evoca claramentea questão da mudança: "V isto queasforças do campo tendem a reforçar asposições dominantes, podemosnos perguntar como verdadeirastransformações das relações de força no seio do campo são possíveis" (2005, p. 38). Asrelações de transação entreprodutores e clientes eas relações deconcorrência internas ao campo econômico (em particular a existência de empresas dominantes e dominadas) constituem o princípio da dinâmica desse campo. D e maneira específica, podem ser identificados cinco fatores de mudança do campo.

Em primeiro lugar, o campo émodificado pelas próprias empresas dominantes na medida em que sua posição só pode ser mantida por um esforço permanente de inovação. G eralmente, é a empresa dominante que toma a iniciativa no que diz respeito ao preço, aos novos produtoseàs estratégias de distribuição e de promoção. M as, "as mudanças no interior do campo são freqüentemente ligadas a mudanças nas relações com o exterior do campo" (Idem, p. 39). Assim, em segundo lugar, as empresas dominantes podem ser suplantadas em decorrência de uma inovação tecnológica que permite uma redução dos custos favorável às empresas dominadas, tipo de modificação em geral introduzido por novosatores, vindo "deoutrossubcampos" (I dem, p. 38). Em terceiro lugar, "às passagens de fronteira juntam-se as redefini ições das fronter ras entre os campos" (I dem, p. 39). Pode acontecer, por exemplo, deum campo se dividir em subcampos especializados (como no caso da indústria aeronáutica), ou de um novo campo emergir da fusão entre várias indústrias, como no caso da informática e das telecomunicações. Em quarto lugar, B ourdieu cita vários fatores externos de mudança: "Astransformações das fontes de abastecimento [...] e as mudanças na demanda determinadas por mudanças na demografia [...] ou nos estilos devida" (Idem, p. 41). Finalmente, um fator fundamental de mudança reside nas interações do campo com o Estado ${ }^{17}$. tégiaso resultado não da escolha individual de um indivíduo racional (o empresário ou o ge rente), mas de lutas internas entre funcionários"detentoresdediferentesespéciesdecapital cultural, com dominantefinanceira, técnica ou comercial" (2005, p. 43). D emaneiraparecida, em Fligstein (1990), encontramos uma análise do confronto interno entre diversas concepções de controle e a predominância sucessiva de cada uma delas, técnica, comercial ou financeira, ao longo do século XX.

$16.0 \mathrm{~s}$ preços provêm de "[...] luta (luta de preços e de concorrência) e de compromisso entreinteresses diversos queocorrem no mercado" (Weber, 1991, p. 57).

17. Percebese aqui que os consumidores representam um elemento muito passivo no modelo teórico de Bourdieu, na medida em que as empresas eo Estado de sempenham um papel preponderanteno processo de mudança. De maneirageral, Bourdieu (2000) empenha-se em mostrar como os consumidores são manipula- 
dos pelas empresas, em particular por meio da propaganda.

18. Como no caso da empresa, Bourdieu (2000) analisa o funcionamento do "campo burocrático", mostrando em que medida as políticas adotadas são 0 resultado delutasinternas.

\section{A intervenção do Estado}

Enquanto a abordagem estrutural da N ova Sociologia Econômica, em particular os trabalhos de Granovetter, não desenvolve uma análise muito aprofundada do papel do Estado na economia, a abordagem política, representada em particular pelas análises de Bourdieu e Fligstein, insiste na importância da atuação do Estado no processo de construção social do mercado (cf. Wanderley, 2002). D e fato, Bourdieu enfatiza a relevância das relações entre o campo econômico e o campo político: "D entre todas as características das sociedades nas quais a ordem econômica está 'imersa', a mais importante, para as sociedades contemporâneas, é a forma e a força de sua tradição estadista" (Bourdieu, 2000, p. 24). Essa importância se deve a uma autonomização simultânea do campo econômico e do campo político.

$M$ ais do que para qualquer outro mercado, Bourdieu mostra que o Estado determina as regras de funcionamento do mercado da casa própria "por meio de toda uma regulamentação específica que se junta à infra-estrutura jurídica (direito de propriedade, direito comercial, direito do trabalho, direito dos contratos etc.) e à regulamentação geral (controle dos preços, enquadramento do crédito etc.)" (Idem, p. 116) ${ }^{18}$. A intervenção do Estado no campo econômico exerce-se, portanto, essencialmente por meio do direito. Ademais, aparece mais uma vez a dimensão política e conflitual do mercado: "Entre todas as trocas com o exterior do campo, as mais importantes são as que se estabelecem com o Estado. A competição entre as empresas assume freqüentemente a forma de uma competição pelo poder sobre o poder do Estado [...] e pelas vantagens asseguradas pelas diferentes intervenções do Estado" (Bourdieu, 2005, pp. 39-40). Assim, o Estado influencia fortemente as relações de força existentes entre os agentes no campo econômico. As empresas dominadas tentam mobilizar seu capital social (suas redes de relações) para pressionar o Estado a modificar as regras do jogo num sentido que Ihes seja mais favorável. 0 Estado participa também da construção da demanda por meio da produção dos sistemas de preferências individuais e da atribuição dos recursos necessários (orientação do crédito, ajudas fiscais etc.). Por exemplo, no caso do mercado da casa própria, mediante as ajudas direcionadas aos indivíduos, o Estado pode favorecer determinada categoria social e, portanto, determinado grupo de construtores. 0 Estado orienta também a demanda por intermédio das normas de qualidade impostas (por exemplo, as construções 
devem respeitar determinados padrões arquitetônicos regionais) e fiscalizadas por funcionários locais (cf. Bourdieu, 2000; 2005).

Bourdieu mostra, assim, quena década de 1960 começou a ser implantada naFrançauma política quevisava afavorecer 0 acesso dosconsumidoresà casa própria. U ma série demedi das que afetavam o sistema bancário público e privado resultou num aumento significativo do financiamento para compra da casa própria, graças a uma redução das taxas de juros, a um alongamento dos prazos dereembolso eà redução do valor da entrada, entreoutros. A pressão dosconstrutores, por intermédio do sindicato profissional, foi fundamental para que o Estado deixasse de investir diretamente (construindo conjuntos habitacionais públicos, cujos apartamentos são alugados por um preço subvencionado para as classes de baixa renda) e para quea moradia in gressasse nalógica do mercado. A implementação, em setembro de 1966, do mercado hipotecário favoreceu um financiamento bancário maciço da construção de casas, quebeneficiou sobretudo as maiores empresas, cujos produtos padronizados, ecom preçosmaisacessíveis, eram destinadosàs categorias sociais menos favorecidas. 0 ministro do Equipamento ${ }^{19}$ da época atendeu as reivindicações do sindicato patronal e estabeleceu como objetivo acelerar o afastamento do Estado eo ingresso da moradianalógica do mercado, ao favorecer 0 acesso à propriedade privada (pelo desenvolvimento dos créditos imobiliários e a oferta de terrenos aos construtores), ao limitar a construção degrandes prédios (ofício de30 denovembro de 1972) eao encorajar a construção de casas (lançando notadamente em março de 1969 um concurso internacional da casa própria). A lei de 16 de julho de 1971, que reorganiza o conjunto das profissões do setor imobiliário, institui o "contrato de construção de casa própria", que assegura aos compradores um conjunto degarantias em relação aos construtores. Em conseqüência, as (grandes) empresas de construção, com base em catálogos (produtos padronizados), desenvolvemse rapidamente ao longo dos anos de 1970 (Bourdieu, 2000)20.

Assim, para Bourdieu, o Estado não é somente encarregado de garantir a ordem e a confiança, e de regular os mercados e as empresas, como tradicionalmente se considera. Como no caso do mercado da casa própria, "ele contribui, às vezes de maneira extremamente decisiva, para a construção da demanda e da oferta" (Bourdieu, 2005, p. 41). Bourdieu apontou para 0 papel do Estado na "gênese social dos sistemas de preferências", ao mostrar que uma parte importante das categorias sociais que teriam respondido favoravelmente a uma política de incentivo à construção de moradias públicas destinadas à locação ingressou, em decorrência do crédito e das aju-
19. Equivalenteao M inistério das Cidadesno Brasil.

20. D e certa maneira, o Estado parece atrelado aos interesses econômicos. 
das do governo, "na lógica da acumulação de patrimônio econômico" (2000, p. 53). Talvez uma das mai ores contribuições de Bourdieu à N ova Sociologia Econômica resi da nessa reflexão sobreos determinantes sociais do comportamento do agente econômico, que passa pela elaboração do conceito dehabitus.

\section{0 agente econômico: habitus e crenças econômicas}

N uma primeira aproximação, a contribuição de Bourdieu à reflexão sobre 0 agente econômico é dupla. D e um lado, ele critica implicitamente 0 pressuposto da ciência econômica do "ator" isolado que toma suas decisões demaneira unilateral; de outro, mostra que, no processo de compra da casa própria (raciocínio que continuaria válido para muitos outros bens), não se pode fazer simplesmente um cálculo de custo e benefício, pois se trata de

21.G arcia-Parpet (2003, p. 150) lembra que, se 0 conceito de habitus como "princípio gerador de estraté gias, sem ser de modo algum o produto de uma verdadeira intenção estratégica", está presentejá nos primeiros textos, como Travail et travailleurs en Algérie (1963), é em Esquissed'unethéoriede la pratique(1972) eem Lesenspratique(1980) que Bourdieu desenvolverá "um conceito geral da ação, operando uma ruptura com a concepção estruturalista dos agentes, que faz deles simplessuportes das estruturas ou executores de regras, e devolvendo-Ihes uma 'espontaneidadecondicionada'". um ato amplamente simbólico que faz intervir outros valores além da pura maximização de uma utilidade econômica.

Bourdieu elaborou sua teoria da ação em reação tanto a uma visão encantada das condutas humanas - de acordo com a qual os agentes respeitariam cegamentenormas e regras sociais- como à visão utilitarista - segundo a qual os interesses individuais seriam osúnicos condicionantes do comportamento dos agentes. Seu postulado sociológico básico éo de queos agentes sociais não agem sem razão, ou seja, eles têm motivos para agir como agem. N essesentido, são "razoáveis", a não confundir com "racionais", o quesignificaria que são motivados por razões conscientes e que escolhem com base num cálculo racional de custo e benefício (cf. Bourdieu, 1996). Por ter condições sociais de exercício, a racionalidade é necessariamente limitada: "A razão (ou a racionalidade) ébounded, limitada, não somente, como crêH erbert Simon, porqueo espírito humano égenericamentelimitado (o quenão éuma descoberta), mas porqueésocial menteestruturado e, em conseqüência, confinado" (Bourdieu, 2005, pp. 47-48). Para entender o comportamento dosatores sociais, épreciso entender que eles atribuam importância, ou seja, interesse (illusio), a um jogo social, a seus objetivos estratégicos. $N$ esse sentido, a noção de interesse opõe-se tanto à de desinteresse como à deindiferença (ataraxia). D izer que os atores sociais são interessadossignifica que eles acreditam nas regras do jogo social.

0 habitus ${ }^{21}$, ou disposição incorporada, depende da posição do agente no espaço social e condiciona, de maneira inconsciente, sua visão de mundo e seu comportamento. 
O s condicionamentos associados a uma classe particular de condições de existência produzem habitus, sistemas de disposições duráveis e transponíveis, estruturas estruturadas predispostas a funcionar como estruturas estruturantes, isto é, como princípios geradores e organizadores de práticas e de representações que podem ser objetivamente adaptadas a seu fim sem supor a intenção consciente de fins e 0 domínio instantâneo das operações necessárias para atingi-los (Bourdieu, 1980a, p. 88).

0 habitus não depende somente da posição social do agente, de sua situação atual, mas também de sua trajetória pessoal. 0 u seja, “o comportamento de cada agente é menos função de suas estratégias e seus cál culos explícitos do que de seu 'senso do jogo', adquirido ao longo de seu itinerário social" (Garcia-Parpet, 2003, p. 150). Isso explica a existência de dife renças entre habitus coletivos, de classe, e habitus individuais. Se Bourdieu reconhece a forte probabilidade de que diferentes indivíduos, "sendo o produto das mesmas condições objetivas, [sejam] dotados dos mesmos habitus", lembra, no entanto, que "o princípio das diferenças entre os habitus individuais reside na singularidade das trajetórias sociais" (Bourdieu, 1980a, pp. 100-101; grifo do autor).

N esse quadro, quais são os princípios de ação do agente econômico na teoria de Bourdieu? D e maneira coerente com sua teoria do campo, Bourdieu mostra que o agente econômico, ou seja, que atua no seio do campo econômico, procura a apropriação máxima do capital específico desse campo, isto é, o capital econômico: "O campo impõe para todos, mas com diversos graus de acordo com sua posição e suas capacidades econômicas, não somente os meios 'razoáveis', mas também os fins, isto é, o enriquecimento individual, da ação econômica" (2000, p. 20). Aparentemente, o agente econômico de Bourdieu agiria, portanto, como o "ator" da ciência econômica22. N o entanto, se osfins são semelhantes, os meios diferem, poisBourdieu critica a visão racional do "ator econômico", preferindo falar deagentes razoáveis, uma vez que, se o agente tem razões para agir, não se trata de um cál culo racional, como vimos. A noção de habitusparece próxima da noção de rotina, da ação tradicional. 0 próprio Bourdieu reconhece que ele "é, portanto, particularmente adaptado às circunstâncias comuns da existência, que [... ] deixam pouco lugar à aval iação conscientee cal culada daschances de lucro" (2005, p. 50). O u seja, nas transações diárias, o agente econômico não se engaja continuamente num cál culo de custo e benefício, mas age como está acostumado a agir, ecom razoável chance de êxito. N o entan-
22. D efato, desdeJ ohn Stuart M ill (1984), a economiapolíticareconhece a existência de uma causa maior do comportamento humano num âmbito particular da sociedade (a esfera econômica): 0 desejo deriqueza, o que legitima a existência dessa ciência. 
23. IBGE francês.

24. Para Hubert Brochier (1987), a identificação do sujeito da ação em Bourdieu nem sempre está clara. M uitas vezes, trata-se deum sujeito coletivo, como a família ou a empresa. D e fato, de acordo com Bourdieu (1994, p. 11), "o 'sujeito' da maioria das estratégias de reprodução é a família agindo como uma espécie de sujeito coletivo e não como um simples agregado de indivíduos".

25. Sobre a análise na Nova Sociologia Econômica das mediações sociais no funcionamento do mercado, ver Steiner (2006). to, reduzir o habitus à noção de rotina empobrece o conceito, que remete também a um princípio gerador de invenções eimprovisações (cf. C hampagnee Christin, 2005).

D e maneira mais concreta, no quadro de seu estudo do mercado da casa própria, Bourdieu (2000) analisa em que medida as preferências dos consumidores são função da posição ocupada no espaço social. Ele critica as pesquisas do I N SEE ${ }^{23}$, que levam em conta diversas variáveis, mas deixam escapar variáveis explicativas importantes, como a trajetória social (pelo menos a profissão do pai) e o capital cultural ou técnico. Assim, com base em dados estatísticos, ele mostra que o comportamento do consumidor depende de vários fatores, como o peso relativo do capital econômico e do capital cultural, que é o princípio da constituição do sistema de preferências, mas também a trajetória social, a idade, a situação matrimonial, 0 número de filhos e o lugar de moradia (tamanho da cidade). 0 bviamente, a probabilidade de se tornar proprietário aumenta com a idade e depende do volume do capital econômico; no entanto, de maneira menos óbvia, a partir de um nível mínimo de capital econômico, a percentagem dos proprietários é mais el evada nas categorias sociais proporcional mente mais ricas em capital econômico (76,8\% dos empresários, 66,1\% dos artesãos e $65 \%$ dos agricultores) do que nas categorias sociais proporcional mente mais ricas em capital cultural (49,9\% dosfuncionários públicos, 49,7\% dosprofessores e 37,2\% nas profissões artísticas). Além disso, "a propensão a atribuir mais importância ao aspecto técnico e menos ao aspecto simbólico da casa cresce à medida que se desce na hierarquia social" (I dem, p. 47). Finalmente, rompendo mais uma vez com os pressupostos da microeconomia, Bourdieu argumenta que "[... ] a decisão econômica não é a de um agente econômico isolado, mas a de um coletivo, grupo, família ou empresa, funcionando à maneira de um campo" (Bourdieu, 2005, p. 18)24. N ão se pode, portanto, deduzir o funcionamento do mercado da hipótese de agentes isolados e intercambiáveis. É preciso analisar a realidade empírica e reconhecer a dimensão coletiva de muitos agentes sociais, além de sua posição na estrutura social.

Encontramos na análise de Bourdieu o mecanismo das mediações sociais, típicas do método sociológico de abordagem dos fenômenos econômicos $^{25}$. Ele insiste na necessidade de analisar a estrutura social específica, "oposta em tudo à noção a-histórica de mercado", para entender como "são efetuadas praticamente a coordenação ea agregação das opções individuais" (I dem, p. 30). Assim, o aj uste da oferta e da demanda não resulta da "agrega- 
ção milagrosa" de inúmeras decisões tomadas por atores interessados e racionais, como no mito da "mão invisível" deAdam Smith, mas da "lógica da orquestração espontânea das práticas, baseada numa rede de homologias (entre os produtos, os vendedores, os compradores etc.)" e numa afinidade entre os habitusdos compradores edos vendedores (cf. Bourdieu, 2000, pp. 97 e 98). O u seja, retomando um modelo analítico que foi aplicado por exemplo ao estudo do campo literário ou religioso, Bourdieu afirma a existência de uma homologia entre as posições dos vendedores e dos clientes (dos bens religiosos, culturais ou econômicos): assim, os clientes dominados, ou seja, quefazem parte dos grupos sociais dominados, tenderiam "naturalmente", isto é, devido a seu habitus, a consumir os bens oferecidos por vendedoresquefazem parte do mesmo universo social. As grandes empresas recrutam, assim, sua equipe comercial no seio dos grupos sociais que compõem sua clientela, como parte de sua estratégia de venda. Com efeito, a heterogeneidade das posições sociais molda os habitus e os estilos de vida, portanto as preferências dos consumidores: "Enquanto 0 economista tende a considerar como exógena a heterogeneidadedas preferênciase das competências dos indivíduos, a abordagem de Pierre Bourdieu interessa-se pelos fatores que determinam a distribuição das diversas formas de capital e por sua evolução no decorrer do tempo" (Boyer, 2003). N esse sentido, a teoria de Bourdieu mobiliza uma lógica diferente daquela das escolhas racionais de "atores" isolados, na medida em que as disposições dos agentes sociais, e portanto suas decisões, são condicionadas por suas condições de existência, o queacarreta uma "redução do lequedeescolhas" (Brochier, 1987, p. 102). Seas contribuições de B ourdieu à análise das mediações sociais dos fenôme nos econômicos são indiscutíveis, al guns autores denunciam a existência de certo determinismo estrutural no seu modelo teórico. Para Alexander (2000), o uso do termo "homologia" simboliza essa falta de autonomia dos campos e sua determinação pela estrutura econômica. 0 s agentes sociais de Bourdieu, longe de mostrarem-se criativos, seriam "motivados por uma estrutura de disposições que traduz simplesmente as estruturas materiais no âmbito subjetivo" (I dem, p. 38). D essa forma, "longe de constituir uma alternativa à explicação social estrutural, o habitus operacionaliza simplesmente esta última" (I dem, p. 41). D e fato, a teoria de Bourdieu, apesar de querer reintroduzir a vontade dos atores sociais na sociologia, numa tentativa de superação da oposição entre objetivismo (o estruturalismo) esubjetivismo (a teoria da ação racional), parece recair em certo determinismo estrutural. Bourdieu afirma que é a posição de cada família "na estrutura da 
distribuição das diferentes espécies de capital" que "orienta as estratégias (e queéo verdadeiro suje to)" (Bourdieu, 1994, p. 11; grifo nosso).

Como salienta Boyer (2003), Bourdieu inova com relação à ciência econômica, ao não diferenciar os indivíduos somente pelo nível de renda, o que Ihe permite explicar resultados inexplicados pelos economistas. Por outro lado, Favereau (2001) identifica a existência de uma mesma lógica espontânea na ciência econômica e na sociologia (econômica) de Bourdieu, e lamenta que a economia presente na sociologia de Bourdieu seja mais um complemento da economia ortodoxa do que um apoio da economia heterodoxa. Ele se esforça assim por mostrar que "o modelo da reprodução segundo Pierre Bourdieu e o modelo da coordenação segundo a atual ortodoxia econômica têm uma estrutura lógica idêntica, caracterizada por uma perfeita ad equação dos esquemas de comportamentos individuais à fabricação da ordem coletiva" (I dem, pp. 279-280). Com efeito, no quadro do modelo analítico de Bourdieu, a maioria das instituições sociais, em particular a escola e a religião, desempenha a função de perpetuar e reproduzir a ordem social, ao assegurar a harmonia entre as disposições individuais e a realidade coletiva. A "lógica da orquestração espontânea das práticas" desemboca numa harmonia na esfera econômica muito parecida com a ordem econômica obtida graças à "mão invisível" (cf. Idem). I gualmente, para Alexander, a socialização em Bourdieu "não transmite valores que estejam em conflito com a experiência vivida; pelo contrário, ela produz valores que refletem imediatamente as estruturas hierárquicas da vida material" (I dem, p. 43). A adesão espontânea dos agentes sociais aos "ideais hegemônicos da classe econômica dominante" está na base dessa teoria da reprodução social (I dem, p. 44). Para Caillé, também, o habitus existe "para garantir a ausência de uma defasagem entre o real e o desejável" (Caillé, 1987, p. 121). D e fato, o mecanismo de formação do habitus desemboca numa conseqüência que tem repercussões sociais fundamentais, isto é, a adequação das "esperanças subjetivas" às "chances objetivas" (Bourdieu, 1980a, p. 90), ou seja, a autolimitação aos projetos de vida "realistas", que funciona como um mecanismo de reprodução do campo (cf. Favereau, 2001). A análise dos projetos de vida dos trabal hadores argelinos leva Bourdieu a afirmar:

A mira do futuro depende estritamente, em sua forma, e em sua modalidade, das potencialidades objetivas que são definidas para cada indivíduo por seu estatuto social epor suas condições materiais de existência. 0 projeto maisindividual nun- 
ca é senão um aspecto das esperanças estatísticas que estão associadas à classe (1979, p. 81).

0 conceito de habitus permite entender por que o comportamento dos agentes econômicos pode revelar-se bem adequado às chances objetivas de êxito, sem ser no entanto o produto de um cálculo racional. "Q uando o habitusé produto de condições objetivas parecidas com aquelas nas quaisfunciona, ele engendra condutas que são perfeitamente adaptadas a essas condições, sem ser o produto de uma busca consciente e intencional da adaptação"26 (Bourdieu, 2005, pp. 53-54). Por ser "relativamente constante edurável", o habituspermitea elaboração de expectativas razoáveisa respeito do comportamento dos outros, baseadas no "postulado tácito de que os outrosagi rão demaneira responsável, ecom o tipo de constância ou defidelidadea si mesmosqueestáinscrito no caráter durável dos habitus" (I dem, pp. 49 e55). Por isso, Bourdieu argumenta quesuateoria "permiteexplicar a verdade aparente" da teoria econômica, mas com base em outras hipóteses (cf. I dem, p. 55). G ostaríamos de apontar para a postura paradoxal deBourdieu, que pretendeter mostrado "[... que várias conquistas da C iência E conômica, espécie de colosso com pés de argila, são perfeitamente compatíveis com umafilosofia do agente, da ação, do tempo edo mundo social completamente diferente daquela que produzem ou aceitam habitual mente a maior parte dos economistas" (I dem, p. 57). O ra, éjustamente a confirmação na realidade do funcionamento do mercado com baseno comportamento do homo oe conomi cusque nos parece problemática. O s esforços de autores da N ova Sociologia Econômica, como Granovetter (1985), Fligstein (1996) ou Zelizer (1988), por exemplo, tendem a comprovar exatamente o contrário. Aliás, 0 próprio Bourdieu reconhece que "vários observadores alertadosnotadamente por economistas de clarividência (ou lucidez) especial, como M aurice Allais, constataram que existe uma defasagem sistemática entre os modelos teóricoseas práticas efetivas" (2000, p. 19). Além disso, seBourdieu concorda com os economistas neoclássicos a respeito do comportamento do agente econômico, elesó sediferencia delespela explicação, ou seja, pelas hipóteses. N esse quadro, como comprovar a veracidade de sua teoria? N a ausência de dados empíricos para determinar a veracidade de uma das duas teorias e descartar a outra, a aceitação deum dosdoisconjuntosdehipótesessó podefundamentar-se num ato de fé, e não num raciocínio objetivo. Em última instância, Bourdieu acaba justificando a posteriori a legitimidade da teoria neoclássica, o queentra em contradição com o próprio objetivo declarado.
26. A eficiência prática do habitus pode ser comprovadaa contrario pela análise das situações nas quais agem agentes dotados de um habitus constituído no quadro de condições sociais totalmentediferentes: "É o caso quando agentes formados numa economia précapital ista são confrontados, desarmados, às exigências de um cosmo capitalista; ou, ainda, quando pessoasidosas perpetuam, na maneira de D om Q uixote, disposições deslocadas; ou quando as disposições de um agente em ascensão ou em declínio na estrutura social estão em dissonância com a posição que ele ocupa" (Bourdieu, 2005, p. 54).

novembro $2007 \quad 221$ 
Falta inclusive indagar se a teoria de Pierre Bourdieu trabalha realmente com "uma filosofia do agente [...] completamente diferente daquela [...] dos economistas". D e fato, muitos autores questionam sua utilização da noção de interesse.

\section{Um agente interessado?}

Aparentemente, 0 agente econômico de Bourdieu não parece muito diferente daquele da ciência econômica, tendo sido acusado de utilitarista por vários autores, sociólogos ou economistas heterodoxos, que concordam sobre sua inserção na "axiomática do interesse" ou numa "antropologia utilitarista" (cf. Alexander, 2000; C aillé, 1986; 1987; Brochier, 1987; Favereau, 2001). Para Alexander, apesar de Bourdieu ter introduzido a noção de habitus como alternativa ao pensamento utilitarista, ela é empregada de tal maneira que "demonstra a onipresença do utilitarismo" (Alexander, 2000, p. 85). Como já vimos, Bourdieu sustenta que toda ação social obedece ao cálculo econômico, pois está sempre orientada pela necessidade de "atingir com o menor custo os objetivos inscritos na lógica de um determinado campo" (Bourdieu, 1980a, p. 85). Caillé (1987) também salienta que os atores sociais de Bourdieu buscam sempre satisfazer seu interesse. Inclusive, atrás do desinteresse aparente da dádiva, escondem-se somente cálculo e interesse. Assim, Bourdieu afirma: "O s universos sociais nos quais o desinteresse é a norma oficial não são, sem dúvida, inteiramente regidos pelo

27. Além disso, a família, que poderia ser considerada o lugar por excelência do desinteresse e dos laços afetivos, assume na teoria de Bourdieu uma dimensão utilitarista: em vez de garantir a segurança afetiva de seus membros, "a unidade da família é feita por e para a acumulação e a transmissão" do patrimônio econômico, social e simbólico (1994, p. 11). desinteresse: por trás da aparência piedosa e virtuosa do desinteresse, há interesses sutis, camuflados" (1996, p. 152). Para que haja troca de dádivas, por exemplo entre os camponeses cabilas, "é preciso [...] que se possa ter interesse pelo desinteresse", ou seja, "que haja recompensas, lucros simbólicos, com freqüência conversíveis em lucros materiais" (I dem, p. 169) ${ }^{27}$. Podese perguntar se esse aspecto "utilitarista" caracterizava a obra inicial de Bourdieu ou se permanece nas reflexões mais atuais.

De fato, as reflexões de Bourdieu sobre o tema são ambíguas. D e um lado, como vimos, ele explicita ter elaborado sua teoria da ação em reação à visão utilitarista que considera os interesses individuais como os únicos condicionantes do comportamento dos agentes sociais. E recusa a assimilação entre sua teoria ea teoria econômica, argumentando que sua concepção do interesse é muito diferente daquela dos economistas. É verdade que sua noção deinteresseémuito ampla, não sendo somentematerial ou econômica no sentido estrito do termo, mas podendo assumir a forma de toda espé 
cie de gratificações simbólicas (cf. Brochier, 1987). D e outro lado, ele afirma a essência "interessada" da natureza humana, recorrendo à noção de libido. "U ma das tarefas da sociologia éa de determinar como o mundo social constitui a libido biológica, pulsão indiferenciada, em libido social, específica. [...] o trabalho de socialização da libido é, precisamente, o que transforma as pulsões em interesses específicos, interesses social mente constituídos" (Bourdieu, 1996, p. 141; grifos do autor). No mesmo texto, recorrendo novamente à terminologia psicanalítica, el eaborda a questão do desinteresse e dos interesses econômicos:

As condutas de honra das sociedades aristocráticas ou précapitalistas têm como princípio uma economia de bens simbólicos fundada no recal que coletivo do interesse [...] que tende a produzir habitus "desinteressados", habitus antieconômicos, dispostos a recalcar os interesses, no sentido estrito do termo (isto é, a busca de lucros econômicos)" (Idem, p. 151)28.

D eacordo com C aillé(1987, p. 139), nas sociedadestradicionais, o nãoreconhecimento do capital econômico e o funcionamento da economia de acordo com a lógica da dádiva participam deuma "hipocrisia coletiva". Com efeito, elas se fundamentam "num conjunto de mecanismos que tendea limitar ea dissimular o jogo do interessee do cálculo econômico" (Bourdieu, 1980a, p. 195). N um texto posterior, Bourdieu insistenaidéia deque, com a modernidade, a lógica econômica passou a impor-se como princípio dominante no campo econômico, "contra o recal que da disposição calculista" (2005, p. 19). I gualmente, no livro sobreo mercado da casa própria, eleserefereà "capacidade, provavelmenteuniversal, desubmeter as condutasà razão calculista" (Bourdieu, 2000, p. 17). Percebe-se, assim, queo utilitarismo dos agentes sociais de Bourdieu permanece presente nos textos mais recentes, que podem ser considerados seu manifesto em sociologia econômica.

Essas frases necessitam de alguns comentários. Em primeiro lugar, Bourdieu parece afirmar a natureza intrinsecamente interessada do ser humano, com um interesse particular pelos benefícios econômicos, sendo o comportamento desinteressado unicamente o resultado de um esforço da sociedade para conter essas pulsões biológicas.

A questão da possibilidade da virtude pode, portanto, ser remetida à questão das condições sociais de possi bilidade em universos nos quais disposições duradouras de desinteresse podem constituir-se e, uma vez constituídas, encontrar condições
28. Eleafirmatambém que "a economia pré capitalista apóia-se fundamentalmente em uma recusa do quenós consideramos como a economia" (1996, p. 172). O ra, só se pode recusar o que se conhece, ou o que é natural, espontâneo. Portanto, Bourdieu parece afirmar aqui a naturalidade do comportamento econômico moderno. 
objetivas de reforço constante, tornando-se o fundamento de uma prática permanente da virtude (Bourdieu, 1996, pp. 152-153).

Além disso, haveria uma tendência natural à busca dos lucros econômicos, e o habi tus desinteressado seria o fruto de um recalque coletivo. Assim, no final do processo de autonomização do mercado,

[...] a economia doméstica passa a ser a exceção. [...] 0 espírito de cálculo, lá reiteradamente recal cado (ainda que a tentação do cálculo nunca estivesse ausente, entre os cabilas como alhures), afirma-se progressivamente, à medida que se desenvolvem as condições favoráveis a seu exercício e a sua afirmação pública (I dem, p. 174; grifo do autor).

29. Como Wacquant (1997, p. 38) observou, Bourdieu segueatradição durkheimiana ao fundamentar suas análises em "comparações binárias, entre sociedades ditas 'tradicionais' ou 'pré-capitalistas' e formações sociais 'altamente diferenciadas".

30. N eil Fligstein, por exemplo, critica ospres supostos do ator racional: "O s atores econômicos vivem em mundos escuros onde nunca é claro quais ações terão quais conseqüências". N essas condições, "nenhum ator podedeterminar quaiscomportamentos maximizarão os lucros" (1996, p. 659). 0 próprio Bourdieu reconhece mais tardea inexistência desse "ator" econômico racional $(2000 ; 2005)$.
Essas afirmações deixam o leitor perplexo a respeito da concepção de natureza humana em Bourdieu.

\section{0 mercado é diabólico?}

Em segundo lugar, no âmbito mais específico da sociologia econômica, Bourdieu parece exagerar as diferenças entre as sociedades tradicionais, em que o desinteresse é estimulado, e a sociedade moderna, na qual os agentes sociais, sobretudo os agentes econômicos, agem de maneira unicamente interessada ${ }^{29}$. No contexto de uma visão típica da sociologia clássica, ele afirma, assim, que "os valores da honra vão se desgastando à medida que as trocas monetárias se generalizam e, por meio delas, o espírito calculista" (Bourdieu, 1996, p. 152). N a sua análise da sociedade camponesa argelina, tende a contrastar sistematicamente, e de maneira talvez um pouco forçada, as disposições e as práticas do camponês tradicional e do agente econômico moderno: "A cautela do fellah, visão antecipada, antecipação pré perceptiva, difere essencialmente da previsão racional do empresário capitalista" (Bourdieu, 1963, p. 27). O u ainda, retomando a análise weberiana: "U m aspecto fundamental das sociedades modernas" reside na "tendência à 'racionalização' (formal) que afeta todos os aspectos da vida econômica" (Bourdieu, 1979, p. 16). O ra, as reflexões atuais, tanto da sociologia econômica como da economia heterodoxa, tendem justamente a ponderar essa visão idealizada do "ator" racional30.

D e maneira geral, Bourdieu parece diabolizar a lógica mercantil que "tende a reduzir qual quer coisa ao estado de mercadoria comprável e a des- 
truir todos os valores" (Bourdieu, 2005, p. 22). Ele inclusive utiliza a dicotomia cara a D urkheim de sagrado e profano: "O mercado é o lugar do cálculo ou até da astúcia diabólica, de transgressão diabólica do sagrado. Ao contrário de tudo o que é exigido pela economia de bens simbólicos, aí um gato é chamado de gato, o interesse de interesse, o lucro de lucro" (Bourdieu, 1996, p. 173). De acordo com a classificação de Zelizer (1988; 1992), Bourdieu adequar-se-ia ao modelo do "mercado ilimitado", que congrega autores que compartilham a visão de um mercado todo poderoso e destrutivo. Estas são as principais premissas desse "revisionismo moral": 1) há uma predominância do mercado na sociedade moderna; 2) existe uma dicotomia entre o mercado visto como relação monetária, independente de qualquer valor, e os val ores não materiais, sagrados, sociais e pessoais; 3) o mercado évisto como uma força expansionista e destruidora dos laços sociais; 4) a intrusão do mercado nos âmbitos pessoal, social e moral da vida leva à degradação/dissolução dos mesmos; e 5) a "proteção" dos valores não-econômicos só é possível por meio de um processo de isolamento. Bourdieu situa-se, assim, numa tradição que se inicia no século XIX eque carrega uma visão pessimista do processo de modernização, cuja expressão se encontra em particular nas obras de M arx, W eber e Simmel. Entre os autores contemporâneos, Zelizer cita Richard T itmuss, cuja comparação internacional dos sistemas de coleta de sangue para transfusão acaba concluindo que os sistemas comerciais, baseados na doação retribuída, não somente são menos eficazes do que a doação voluntária (gratuita), como também representam um perigo para a ordem social. 0 ra, Titmuss é justamente um dos autores mobilizados por Bourdieu (2005) para sustentar sua própria argumentação.

Zelizer critica os autores defensores do modelo do mercado ilimitado por estarem próximos dos economistas clássicos, ao reconhecer "as possibilidades de expansão ilimitada do mercado, ignorando suas limitações estruturais, culturais e sociais" (1992, p. 6). Rejeitando a autonomização e a diabolização do mercado apontadas por esse modelo, Zelizer recusa a dicotomia entre processos econômicos e forças socioculturais para afirmar que os processos econômicos deveriam ser vistos como "uma categoria especial de relações sociais", como a religião ou o parentesco (1988, p. 619). Em seu modelo dos "mercados múltiplos", a autora esforça-se para mostrar como a cultura e as relações sociais se ap ropriam das relações econômicas e as moldam. "As relações sociais e os valores não se submetem passivamente a um mercado potente ehomogeneizador", mas são "as diferentesformas de rela- 
31. Bourdieu leva em conta não só as condiçõesculturais, mastambém econômicas, do acesso à conduta racional. Assim, conseguiu comprovar empiricamente que "abaixo de certo patamar de segurança econômica, assegurada pela estabilidade do emprego ea possessão de um mínimo de rendas regulares, os agentes econômicos não podem conceber nem realizar a maioria das condutas que supõem um esforço para apreender o futuro, como a poupança ou 0 crédito" (2003, p. 85).

32. Frédéric Lebaron, aluno de Bourdieu, dá continuidade a essas reflexões ao analisar o papel político da teoria econômica e seu estatuto de "substituto laicizado da fé religiosa" (2000, p. 7).

33. Ele faz referência, por exemplo, ao esforço que devem realizar os camponeses para abandonar uma visão da "atividadecomo ocupação social socialmentereconhecida, independentemente de qualquer sanção material" (2003, p. 83; grifo do autor), e lembra a reflexão de Weber (1987) a respei- ções sociais que determinam mercados múltiplos ao criar de maneira dinâmica novos modos de troca e repartição" (Zelizer, 1992, p. 24). N ão pretendemos desenvolver neste artigo as análises de Z elizer, que são mobilizadas apenas para sugerir em que direção, frutífera, uma sociologia econômica pode orientar suas reflexões.

\section{As crenças econômicas}

No entanto, a análise de Bourdieu não pára por aí, e ele oferece uma reflexão extremamente interessante em termos de crenças econômicas. M ostra, já em 1963, que "a conduta econômica supõe um conjunto de valores sociais que a orienta”, em particular "a existência deum sistema determinado de atitudes diante do mundo edo tempo"31 (Bourdieu, 1963, pp. 24 e 25). Ele retoma essa idéia na sua análise do mercado da casa própria, ao afirmar queas disposi ções do agente econômico moderno - como as necessidades, as preferências, a propensão ao trabalho assalariado, à poupança, ao investimento ou ao crédito, por exemplo - , longe de serem naturais e universais, são social e historicamente construídas. Com efeito, elas são o "produto de toda uma história coletiva, que deve ser sempre reproduzida nas histórias individuais" (2005, p. 19). 0 universo econômico é, como qualquer outro campo, um "universo de crença" ${ }^{32}$, ou seja, os agentes devem acreditar no jogo, eles devem ter a certeza de que vale a pena jogar e devem aprender elegitimar as regras do jogo (I dem, p. 17). A análise das transformações das práticas econômicas no meio rural argelino na década de 1960 permitiu a Bourdieu tomar consciência de que se tratava menos de um processo de adaptação do que de "conversão" a um novo "sistema de crenças" 33 (2003, pp. 82 e 83; grifo do autor). Como em Weber, encontramos em Bourdieu a convicção de que é a sociedade que legitima os fins e os meios dos agentes econômicos: "O sistema econômico em via de racionalização tende a moldar os sujeitos conforme suas expectativas e suas exigências" (1963, p. 25). Por exemplo, Bourdieu lembra que o interesse por certos tipos de bensnão éinato, masédado socialmente: assim, o uso social da casa própria supõe uma "Ionga tradição de sedentariedade. [... ] Ele é solidário a uma visão conservadora do mundo, queval oriza to das as formas de enraizamento" (2000, p. 36). Além disso, as revistas femininas e dedicadas à casa "moldam as expectativas em termos de moradia, ao dar como exemplo sua arte de viver" (I dem, p. 113). N o caso da casa própria, a dimensão simbólica desempenha um papel fundamental. Trata-se de um investimento não so- 
menteeconômico, mastambém social eafetivo que encerra um "projeto de reprodução biológico e social" (I dem, p. 36). A forte ligação existente entre os projetos de "construir uma casa" e "construir uma família" revela-se na fraca percentagem de solteiros proprietários de casa. "A casa é indissociável do lar como grupo social durável e do projeto coletivo de perpetuá-lo" (Idem, p. 34). Aliás, esse componente emocional da casa, "produto da coesão afetiva que reforça a coesão afetiva" (I dem, p. 35), não passou despercebido eé um elemento fortemente val orizado nas propagandas ${ }^{34}$.

A essas "representações espontâneas", que decorrem do próprio funcionamento da atividade econômica, devem ser acrescentadas as "representações construídas" por uma instituição (como o sistema escolar) ou por organizações (onde operam os peritos) encarregadas de difundir o saber econômico junto aos produtores e aos consumidores (cf. Steiner, 2005). N o seio das instituições, Bourdieu (2000) distingue entre as estruturas objetivas (administrativas, notadamente) e as estruturas cognitivas, e as disposições que as primeiras contribuíram para produzir. Ele alude, assim, ao processo de legitimação da teoria econômica levado adiante por vários agentes e instituições, e denuncia, em particular, a difusão do pensamento neoliberal por instituições internacionais como o Banco M undial ou 0 FM I. E, no caso específico da casa própria, mostra que a emergência da lógica de mercado nessa área resultou de uma luta interna ao Estado entre altos funcionários de diversos ministérios, em que prevaleceu o discurso fundamentado num cálculo de custo e benefício. 0 rigor dos modelos econométricos assimilados por al guns funcionários no decorrer de sua formação acadêmica forneceu a autoridade necessária para legitimar o discurso reformador.

D evemos finalmente levar em conta o que Bourdieu chamou de "efeitos de teoria", ao mostrar que a difusão das teorias econômicas no conjunto da população, por meio da profissionalização dos economistas e dos debates suscitados por seus modelos, constitui um elemento fundamental para entender a implementação e a difusão da lógica mercantil (cf. G arcia-Parpet, 2003). O u seja, como D urkheim (1984) ou Polanyi (1980) tinham rapidamente apontado antes dele, a divulgação da "descoberta" das leis de funcionamento do mercado, apresentadas como possuidoras da veracidade e da necessidade dos fenômenos naturais, participou da aproximação cada vez maior do comportamento dos agentes econômicos com os pressupostos do homo oeconomi cuse da elaboração dos arranjos institucionais que permitem o funcionamento do mercado. to do trabal ho realizado como "vocação": "Um tal estado de espírito não é um produto da natureza. $N$ ão podeser suscitado unicamente por altosou baixossalários. É o resultado de um longo processo de educação".

34. Essa particularidade da casa própria (investimento financeiramente pesado esimbolicamente forte) inviabiliza talvez uma generalização das reflexões deBourdieu aosoutros setores da economia. 
À medida que evolui, a organização econômica tende a impor-se como um sistema quase autônomo que espera e exige do indivíduo um certo tipo de prática e de disposições econômicas: adquirido e assimilado insensivelmente por meio da educação implícita e explícita, o espírito de cálculo e de previsão tende desse modo a aparecer como incontestável porque a "racionalização" é a atmosfera da qual se alimenta (Bourdieu, 1979, p. 15).

\section{Considerações finais}

Bourdieu conseguiu elaborar uma sociologia econômica apta a substituir a ciência econômica, sobretudo no que tange ao pressuposto do "ator" econômico interessado? D e um lado, a sociologia econômica de Bourdieu inova ao levar em conta três dimensões esquecidas pela ciência econômica, como bem apontou Steiner (2005). Em primeiro lugar, a dimensão política está presente na reflexão a respeito dos agentes econômicos desiguais, das barrei ras à entrada de novas empresas no mercado e das relações de poder presentes no campo econômico (o mercado como campo de lutas), bem como na análise do papel do Estado na construção da oferta e da demanda, e de sua influência sobre as relações de poder existentes entre os agentes econômicos. Essas lutas de poder e a intervenção do Estado constituem os principais fatores de mudança no campo econômico. Em seguida, as reflexões sobre as diferenças existentes entre soci edades tradicionais e sociedade moderna, assim como a caracterização do universo econômico como universo de crença, lentamente construído e legitimado por um conjunto de valores sociais, evidenciam a dimensão histórica. Finalmente, a dimensão social podeser encontrada na análise das condições econômicas e sociais das disposições econômicas e na reflexão sobre a decisão econômica, vista não como a de um agenteisolado, mas como a de um agente coletivo, família ou empresa, funcionando à maneira de um campo. Trata-se de uma análise genuinamente sociológica dos fenômenos econômicos, uma vez que o sociólogo francês aplica seu quadro analítico, articulado ao redor dos conceitoschave de campo e habitus, à esfera econômica, o que Ihe permite revelar aspectosignorados pela ciência econômica. N esse sentido, pode-se considerar Bourdieu como pertencente à tradição francesa da sociologia econômica, ao mesmo tempo em que compartilha com os autores da N ova Sociologia Econômica a análise do mercado em termos de construção social.

No entanto, apesar dessas contribuiç̧ões fundamentais, parece subsistir certa ambigüidade a respeito do caráter inato ou adquirido do "espírito 
calculista" no agente econômico de Bourdieu, assim como a respeito da existência de uma esfera econômica distinta, obedecendo a uma lógica própria. D o nosso ponto de vista, Bourdieu tende a exagerar as diferenças existentes entre economia tradicional, baseada na lógica da reci procidade e em valores éticos como a honra e a leal dade, e economia moderna, baseada no cálculo e na busca do interesse individual. $N$ esse sentido, ao denunciar os efeitos sociais e morais negativos do mercado, ele parece diabolizar a lógica mercantil, o que vai na contramão dos esforços atuais dos autores da N ova Sociologia Econômica.

Referências Bibliográficas

Alexan der, Jeffrey. (2000), La réduction: critique de Bourdieu. Paris, Les Editions du Cerf.

Bourdieu, Pierre. (1963), "La société traditionnelle: attitude à l'égard du temps et conduite économique". Sociologie du Travail, 5 (1): 24-44. . (1979), 0 desencantamento do mundo. São Paulo, Perspectiva. . (1980a), Le sens pratique. Paris, M inuit. . (1980b), Q uestions de sociologie. Paris, M inuit. . (1994), "Stratégies de reproduction et modes de domination". Actes de la Recherche en Sciences Sociales, 105: 3-12.

. (1996), Razões práticas: sobre a teoria da ação. C ampinas, Papirus.

. (2000), Les structures sociales de l'économie. Paris, Seuil.

. (2003), "La fabrique de I'habitus économique”. Actes dela Recherche en Sciences Sociales, 150: 79-90.

. (2005), "O campo econômico". Política \& Sociedade, 6: 15-58 (tradução de “Le champ économique". Actes dela Recherche en Sciences Sociales, 119: 48-66, 1997).

Bourdieu, Pierre, Chamboredon, J.-C. \& Passeron, J.-C. (1968), Le métier de sociologue. Paris-La H aye, M outon.

BOYER, R obert. (2003), "L'anthropologie économique de Pierre Bourdieu”. Actes dela Recherche en Sciences Sociales, 150: 65-78.

Brochier, Hubert. (1987), "La sociologie de Pierre Bourdieu et l'individualisme méthodologique". Bulletin du M AU SS, 22: 87-106.

C AIllé, Alain. (1986), Splendeurset misères des sciences sociales: esqui sses d'une mythologie. Genebra, D roz.

. (1987), “C ritique de Pierre Bourdieu: 1. L'économisme”. Bulletin du M AU SS, 22: 107-154. 
Champagne, Patrick \& Christin, O livier. (2005), M ouvements d'une pensée: Pierre Bourdieu. Paris, Bordas.

Convert, Bernard. (2003), "Bourdieu: Gary Becker'scritic". Economic Sociology European Electronic N ewsletter, 4 (2). Consultado no site http://econsoc.mpifg.de.

D IM AG GIO, Paul \& LoucH, H ugh. (1998), "Socially embedded consumer transactions: for what kinds of purchases do people most often use networks?". American Sociological Review, 63: 619-637.

D urkheim , Émile. (1975), "Sociologia e ciências sociais". In: A ciência social e a ação. São Paulo, Difel, pp. 125-142.

. (1984), As regras do método sociológico. 11. ed. São Paulo, Editora N acional. . (1995), D a divisão do trabalho social. São Paulo, M artins Fontes.

Em IRBAYER, M ustafá. (1997), “M anifesto for a relational sociology”. American Journal of Sociology, 103 (2): 281-317.

Favereau, Olivier. (2001), “L'économie du sociologue ou: penser (l'orthodoxie) à partir de Pierre Bourdieu". In: LAHIRE, Bernard (org.). Le travail sociologique de Pierre Bourdieu: dettes et critiques. Paris, La D écouverte, pp. 255-314.

Fligstein, N eil. (1990), The transformation of corporate control. Cambridge, $\mathrm{H}$ arvard University Press.

. (1996), "M arkets as politics: a political-cultural approach to market institutions". American Sociological Review, 61: 656-673.

G arcia-ParPet, M arie-France. (2003), "D es outsiders dans l'économie de marché: Pierre Bourdieu et les travaux sur l'Algérie". Awal, 27/28: 139-152.

G ran ovetter, M ark. (1974), Getting a job: a study of contacts and careers. C ambridge, $\mathrm{H}$ arvard University Press. . (1985), "Economic action and social structure: the problem of embeddedness". American Journal of Sociology, 91 (3): 481-510.

LaHIRE, Bernard. (2001), "C hamp, hors-champ, contrechamp". In: (org.). Letra-

vail sociologi quedePierreB ourdieu: detteset critiques. Paris, LaD écouverte, pp. 23-57. Lebaron , Frédéric. (2000), La croyance économique: les économistes entre science et politique. Paris, Seuil. . (2001), "Bases of a sociological economy: from François Simiand and M aurice $\mathrm{H}$ albwachs to Pierre Bourdieu". International Journal of Contemporary Sociology, 38 (1): 54-63.

M Auss, M arcel. (2001), Ensaio sobrea dádiva. Lisboa, Edições 70.

PolAnYI, Karl. (1980), A grande tranforormação. Rio de Janeiro, Campus.

Raud-M ATtedı, Cécile. (2005a), "A construção social do mercado em Durkheim e Weber: análise do papel das instituições na sociologia econômica clássica”. Revista Brasileira de Ciências Sociais, 57: 127-142. 
. (2005b), "Análise crítica da sociologia econômica de M ark Granovetter: os limites de uma leitura do mercado em termos de redes e imbricação". Política \& Sociedade, 6:59-82.

Stein ER, Philippe. (1998), "La nouvelle sociologie économique, l'analyse structurale et la théorie économique". C ahiers d'E conomie Politique, 33: 107-135. . (2002), “Encastrement et sociologieéconomique”. In: H uault, Isabelle (org.). La construction sociale de l'entreprise: autour des travaux de M ark Granovetter. Colombelles, Editions EM S, pp. 29-50. . (2005), Comte - D urkheim - Bourdieu: la tradition française de critique sociologique de l'économie politique. Comunicação apresentada no Colóquio Tradições $\mathrm{N}$ acionais em Ciências Sociais. Amsterdam, Amsterdam School for Social Science Research, 6-7 de maio. . (2006), A sociologia econômica. São Paulo, Atlas.

Stuart M ILL, John. (1984), "D a definição de economia política e do método de investigação próprio a ela". In: Stuart M ill, Bentham. 3. ed. São Paulo, Abril Cultural, pp. 293-319 (col. Os Pensadores).

SwED BeRG, Richard. (1991), "M ajor traditions of economic sociology". Annual Review of Sociology, 17: 251-276.

. (2003), "Bourdieu's advocacy of the concept of interest and its rolein economic sociology". Economic Sociology European Electronic N ewstetter, 4 (2). Consultado no site http://econsoc.mpifg.de.

. (2004), "Sociologia econômica: hoje e amanhã". Tempo Social, 16 (2): 7-34.

W Acquant, Loïc. (1997), "D urkheim e Bourdieu: a base comum e suas fissuras". N ovos Estudos Cebrap, 48: 29-38.

W an derley, Fernanda. (2002), "Avanços e desafios da N ova Sociologia Econômica: notas sobre os estudos sociológicos do mercado: uma introdução". Sociedade e Estado, 17 (1): 15-38.

W EBER, M ax. (1987), A ética protetante eo espírito do capitalismo. São Paulo, Pioneira. . (1991), Economia e sociedade. Brasília, U nB.

W HITE, H arrison. (1981), "Where do markets come from?". American Journal of Sociology, 87 (3): 517-547.

Zelzer, Viviana. (1988), "Beyond thepolemics on the market: establishing atheoretical and empirical agenda". Sociological Forum, 3 (4): 614-634.

. (1992), "Repenser le marché. La construction sociale du 'marché aux bébés' aux Etats-Unis, 1870-1930". Actes de la Recherche en Sciences Sociales, 94: 3-26. 


\section{Resumo}

Bourdieu e a nova sociologia econômica

Este artigo objetiva analisar a sociologia do mercado de Pierre Bourdieu, a fim de avaliar os alcances e os limites do pensamento de um dos autores mais representativos da N ova Sociologia Econômica francesa. Com base na leitura crítica de alguns textos selecionados, chegamos à conclusão de que se trata de uma análise genuinamente sociológica dos fenômenos econômicos, uma vez que o sociólogo francês aplica seu quadro analítico, articulado ao redor dos conceitos-chave de campo e habitus, à esfera econômica, mostrando que o mercado éo produto de uma construção social. Além de destacar a gênese social das disposições econômicas e de caracterizar o mercado como um campo de lutas onde se enfrentam agentes dotados de recursos diferentes, Bourdieu insiste no papel do Estado na regulação desse mercado, mobilizando dessa maneira, ao mesmo tempo, uma sociologia do conhecimento e uma sociologia política na sua análise da esfera econômica. N o entanto, apesar de uma reflexão pioneira em termos de crenças econômicas, a abordagem de Bourdieu apresenta uma série de limitações que dizem respeito, entre outras, a certa ambigüidade no que tange às motivações do agente econômico moderno e à delimitação da esfera econômica.

Palavras-chave: M ercado; Habitus; Campo econômico; Pierre Bourdieu; Sociologia Econômica.

\section{Abstract}

Pierre Bourdieu's contribution to the new economic sociology

This article examines Pierre Bourdieu's sociology of the market, assessing both the scope and limits of the thinking of one of the most emblematic authors of the $\mathrm{New}$ French Economic Sociology. Following a critical reading of some of his key texts, the article argues that Bourdieu's work involves a genuinely sociological analysis of economic phenomena, insofar as he applies his analytic framework - structured around

Texto recebido em 16/ 2/2006 e aprovado em $4 / 12 / 2006$.

Cécile Raud é professoraadjunta do Programa de Pós-Graduação em Sociologia Política da U niversidade Federal de Santa Catarina. E-mail: cecile@cfh.ufs c.br. the key concepts of field and habitus - to the economic sphere, showing that the market is the product of a social construction. Aswell as highlighting the social genesis of economic dispositions and describing the market as a field of struggles where agents with different resources confront each other, Bourdieu insists on the role of the State in regulating this market. In analyzing the economic sphere, he makes use simultaneously of a sociology of knowledge and a political sociology. H owever, although a pioneering analysis of economic beliefs, Bourdieu's approach presents a series of limitations, including a certain ambiguity in relation to the motivations of modern economic agents and the delimitation of the economic sphere.

Keywords: M arket; H abitus; Economic Field; Pierre Bourdieu; Economic Sociology. 